\title{
THE CRISIS IN THE WORLD ECONOMY - SOME THOUGHTS ON THE SITUATION TODAY AND IN THE THIRTIES
}

\author{
R.C. Wanigatunga \\ Commonwealth Secretariat
}

\begin{abstract}
"Economics still does not allow final answers on these matters. But as usual, something can be said." J.K. Galbraith in The Great Crash.
\end{abstract}

I.

\section{Introduction}

There is mounting anxiety that the world economy is currently in the throes of a recessionl/ which could well escalate into a severe depression similar to that which bedevilled most countries in the inter-war period.

It is perhaps useful briefly to see the background to the current recession and then examine its salient features and attempt to assess its possible causes. The policies adopted to deal with it are also relevant. The inter war period is treated likewise. Finally, a brief comparison of the two periods is made.

In both periods, what is being dealt with is a malaise of the developed market economies, which has, of course, had severe repercussions for the rest of the world, none more so than the developing countries considered as a group. The developed market economies, led by the US, account for much of world income and trade and their dominance was even greater in the 20 s and $30 \mathrm{~s}$ (Table 1 ).

\section{The Current Recession}

\section{The background}

The post Korean war period up to the mid 60 s saw a rapid rate of growth of world income and of world trade (tables 2-4): the latter was greatly assisted by trade liberalisation in industrialised countries (albeit concentrated on intra-regional western European trade) and the "convertibility" of major currencies. In the developed economies, the numbers in employment rose sharply and the rate of unemplcyment remained low (Table 5), while the general level of prices rose only mildly. This period was alsc characterised for the most part by a high and sustained level of aggregate demand, at a level very often approximately that necessary to maintain "full employment", partly as a result of the following of "Keynesian"economic policies $2 /$ in most countries, and rising real expenditure on durable consumer and "public" goods. 
Among the "leading sectors" for which there was great demand (and which indirectly fuelled growth) were the automotive industry (and services and industries "linked" to it), consumer electrical goods, i.e. the "leading sectors" of "high mass consumption, " $3 /$ services such as tourism associated with the increased use of leisure, and services relating to education and health.

On the supply side, relative prices of primary products, especially of energy, were low. There were significant advances in overall productivity due to shifts of resources, particularly labour, from agriculture, and advances in technology.

By the later 60s, however, the rate of growth of output was beginning to falter and other ominous developments were discernible. The marginal capital-output ratios were rising 4 / and the rate of return to capital 5 showed a tendency to fall. There was an observable decline in the rate of expansion of the "leading sectors" and a failure for others to counterbalance this trend. The numbers employed in most OECD countries were not increasing as rapidly as before, but unemployment was not a major problem as yet.

International trade, however, continued to expand, partly as a result of further trade liberalisation and the increase in intra-industry specialisation.

\section{Current recession}

From the early 70 s right up to 1982 the OECD economies have behaved very erratically (tables 4 and 5) and there have been very disturbing developments in relation to the rate of growth of output, unemployment levels and rates, inflation and in international trade.

The economies of most OECD countries went into recession in 1974/75, with GNP stagnating, while over the previous two years it had grown by over 11 per cent. The decline in GNP was accompanied by the highest rate of inflation since 1945 , with consumer prices increasing by nearly 25 per cent over 1974 and 1975.6/ Unemployment levels and rates tended to rise. International triále slowed down.

There were some improvements in most areas (with the notable exception of employment) between 1975 and 1979, followed by a second recession far worse in its effects than the earlier one, with real output stagnating over the period 1979-82 and unemployment rising rapidly (since 1980) to rates which though significantly below the average rates of the inter-war period are, nevertheless, historically very high. The rates of return to capital and investmentI/ (levels and 
lable 1 - Selected_Countries and Country Groupings in relation to World Trade and Income

(figuresin per cent)

\begin{tabular}{|c|c|c|c|c|c|c|c|c|c|}
\hline \multirow{2}{*}{ Countries/Groupings } & \multicolumn{6}{|c|}{ Tradet } & \multicolumn{3}{|c|}{ Income } \\
\hline & $1 \overline{9} \overline{8}$ & 1938 & .1950 & 1960 & 1970 & 1981 & 1929 & 1970 & 1080 \\
\hline North America & 16,1 & 12.2 & 18.4 & 15.3 & 16.2 & $16 . \overline{7}$ & 38.3 & 34.6 & $24, \overline{3}$ \\
\hline & & . & & & 12,1 & 13. & & 32.0 & \\
\hline lestern Europe & $48.2^{2}, 3$ & $47 \cdot 5^{2}, 3$ & $37.7^{2}$ & 40,6 & 43.5 & 40.9 & $32.4^{4}$ & 25.4 & 29.4 \\
\hline 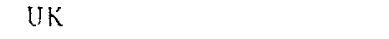 & $\cdots$ & . & 11.1 & 9. & & $5 \cdot 4$ & . & $3 \cdot 9$ & $4 \cdot 4$ \\
\hline & . & . & 4.8 & 4. & 5 . & 6.0 & . & 4.8 & $5 \cdot 5$ \\
\hline & . & . & 4. & & & 8. & - & 6.0 & 6. \\
\hline Jap & . & . & 1.5 & $3 \cdot 3$ & 5.8 & 7.0 & 2.1 & 6.3 & 6.9 \\
\hline $\begin{array}{l}\text { Total Indu } \\
\text { Areas } 5\end{array}$ & 67.6 & 63.5 & 57.6 & 59.2 & 65.5 & $61: 8$ & 72.8 & 66.4 & 62.9 \\
\hline
\end{tabular}

. not avaitabie.

1. Imports. 2. Excludes Spain, Yugoslavia and Gibraltar. 3. Excludes Finland. 4. North West and South East Europe. 5. Excludes South Africa and Australasja. Sources: For trade data before 1960, GATT (Report by a panel of Experts), Trends in International Trade (Geneva, 1958) pp $12-15$ and for subsecuent trade data GATT Internationa1.Trade (various): for pre-war data on income, A.J.ll. Latham The hepnession in the Developing World (Croom llelm, London 1981) p.153 and for later data on income, calculations from UNCTAD Trade and Development statistics (various).

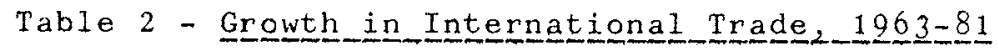

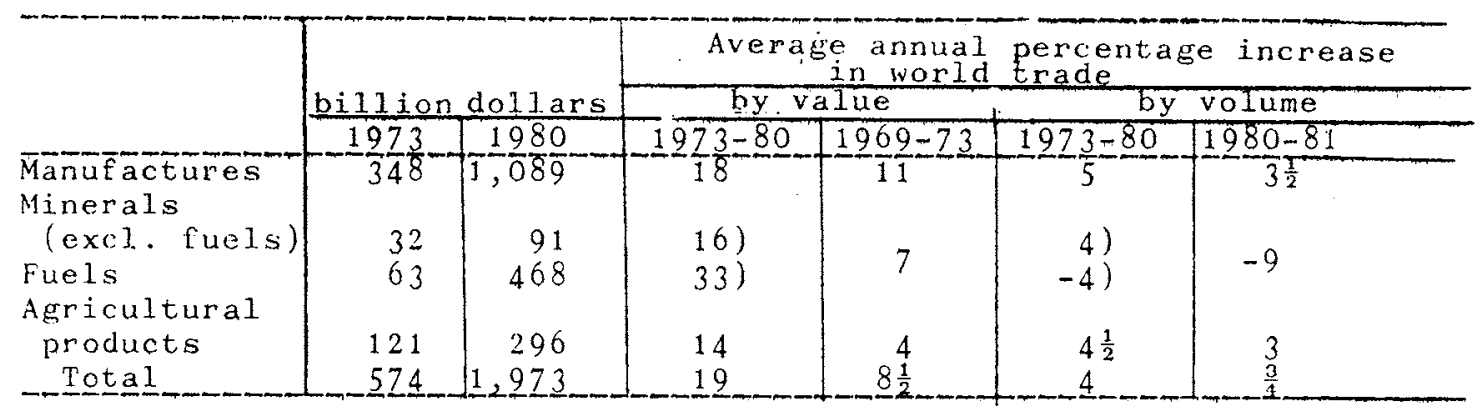

Source: Commonwealth Secretariat. Protectionism: Threat to International Order (1982) p.6. 


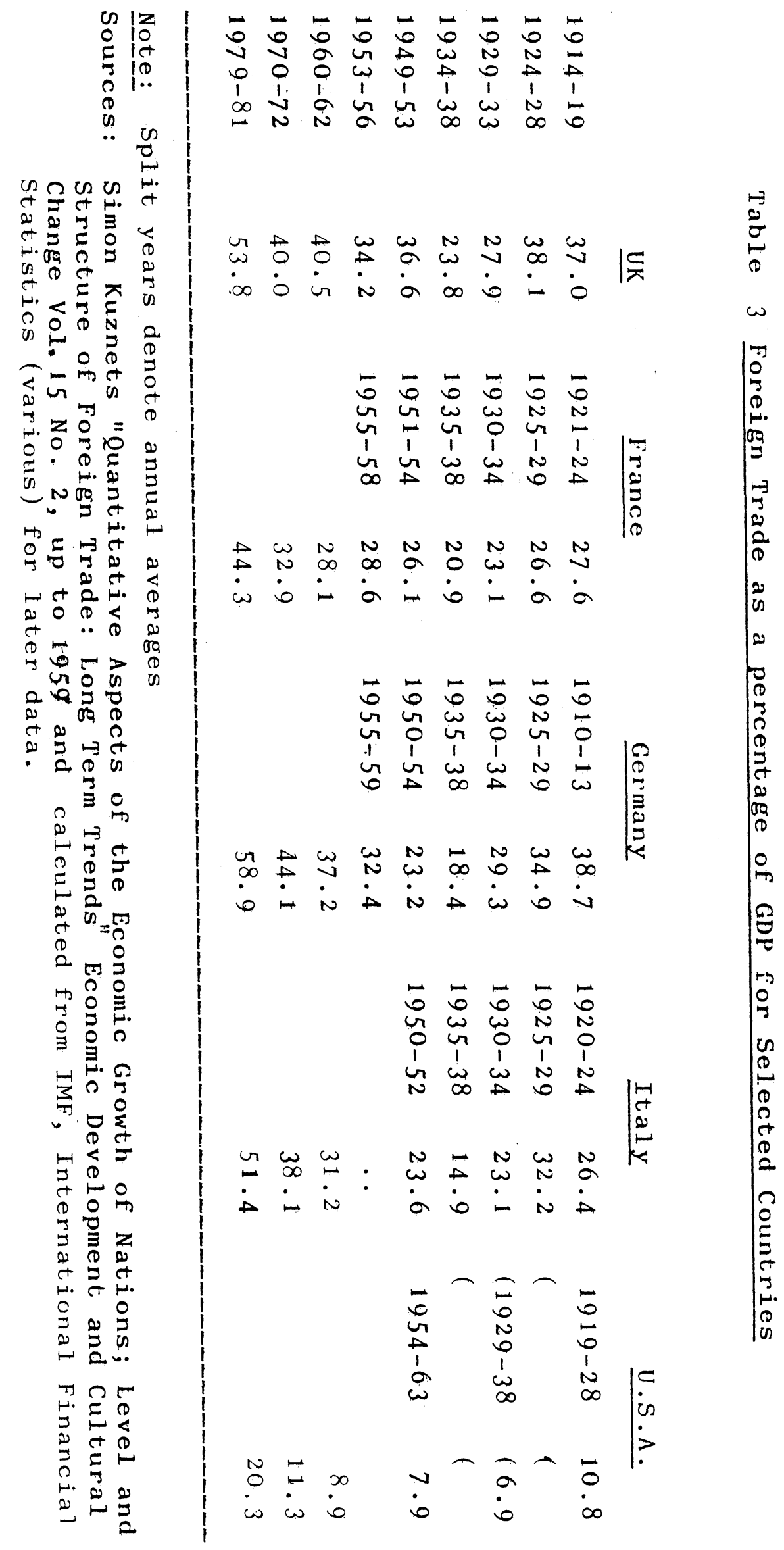




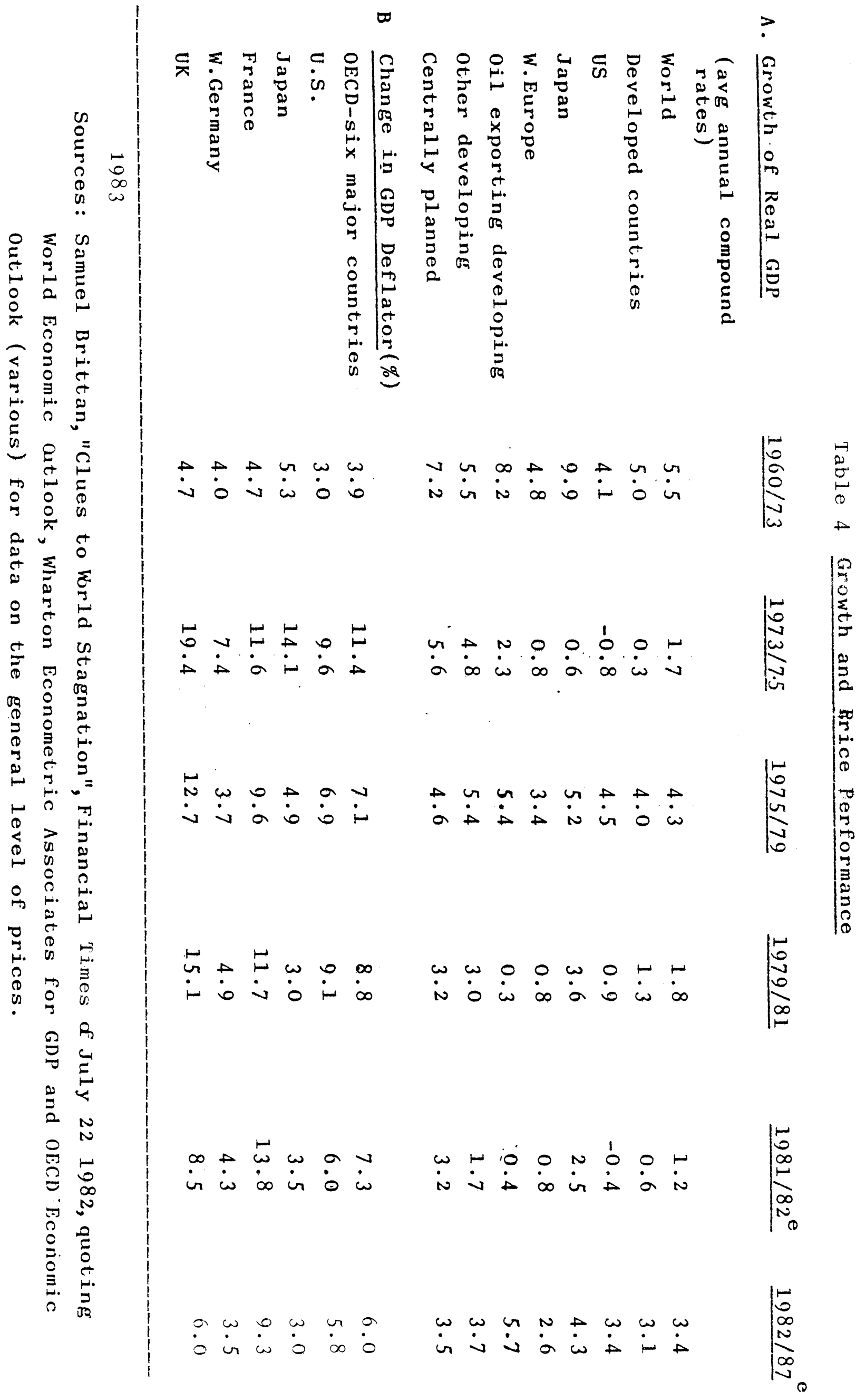


Table 5 Unemployment Data for Selected Economies

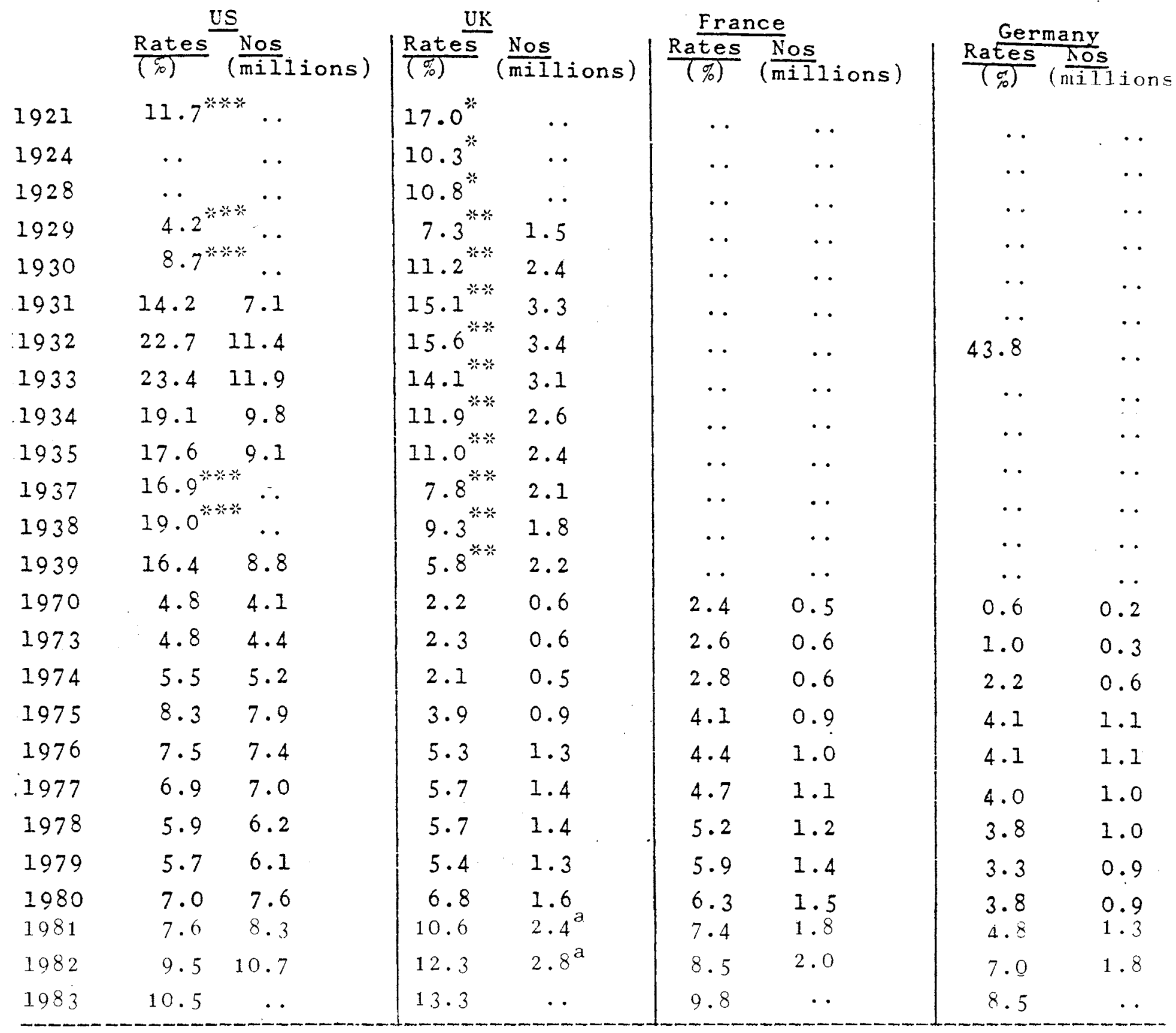

not available.

a Excluding school leavers.

* These rates are computed on the basis of trade union membership and are somewhat higher that they would be if otherwise computed.

Estimates on basis of revisions of figure of *type by Jim Tomlinson.

Anna Schwartz's estimates.

Sources: The Beveridge Report (H.M.S.O.London,1942) pp.24 and 107, Jim Tomlinson "Unenployment and Policy in the 1930 s and 1980s" Three Banks Review, September $1982 \mathrm{pp} 18$ and 20 , OECD, Labour Force Statistics 1969-80 and OECD, Economic Outlook, (various), Anna Schwartz "Understanding 1929-38" in Karl Brunner (ed) The Great Depression Revisited (Nijhoff, The Hague, 1980) p.17 and OFCD Main Economic Indicators, August 1983 . 
rates) began to deteriorate progressively: real wages tended to run ahead of productivity, which itself was declining in the manufacturing as well as in other sectors/, especially after 1972-74.

The rate of inflation in a number of OECD countries rose sharply in 1979 but has declined since 1981 in response to "tight" monetary (and often fiscal) policies. The volume of international trade was estimated to be lower in 1983 than three years previously. 9 /

Table 6 - The Declining Role of Manufacturing in Selected OECD (figures in percentages)

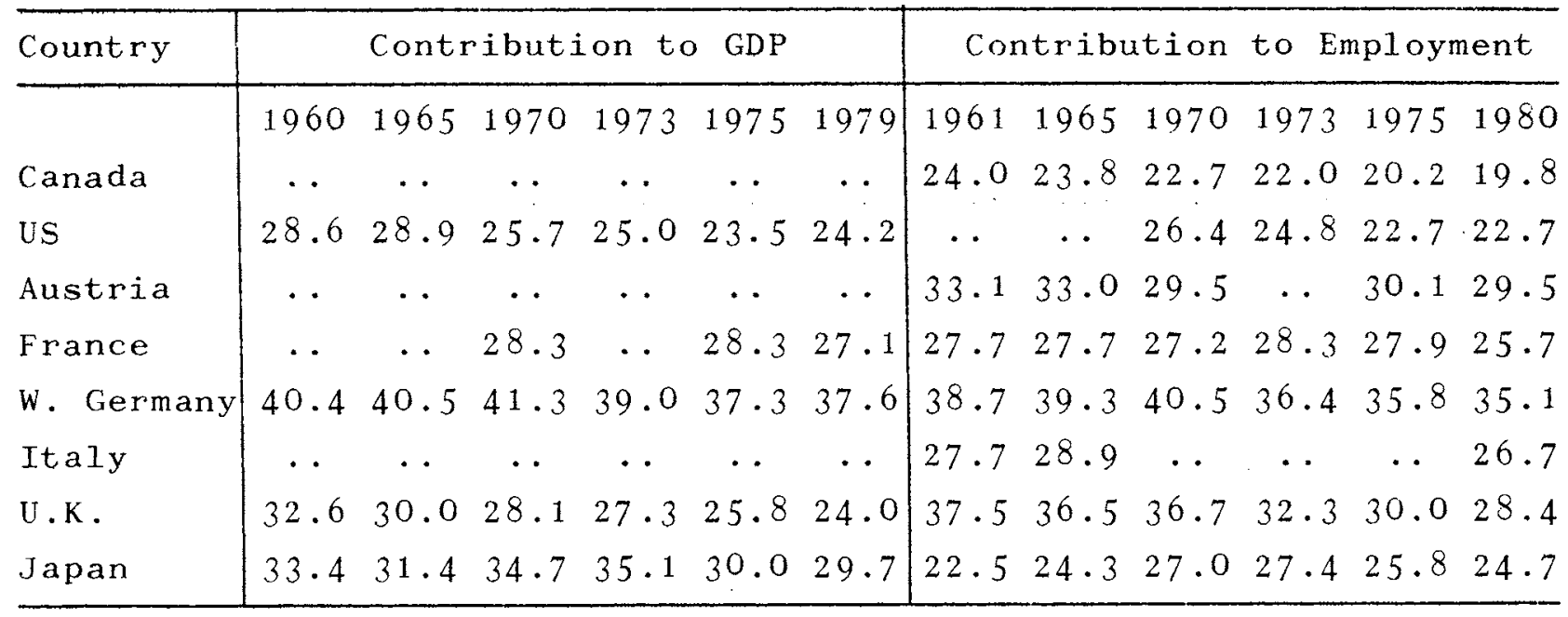

Sources: OECD, Labour Fcrce Statistics 1961-72 and 1969-80, and UN Yearbook of National Accounts Statistics (various)

\section{Possible causes for recession}

The causes of the current recession are a subject for much vigorous debate among economists - as indeed are still those for the inter-war depression! Some variability in real performance is virtually inevitable even under the "the smoothest monetary policy" 10 and there was clearly a need, emerging well before the oil price "shock" of October 1973, for structural"adjustment" or investment in new leading growth areas. 11 The relative decline (and in absolute terms virtual stagnation or decline when 1982 is compared with $1977 / 78$ ) of the manufacturing sector, which still accounts for a substantial proportion of output in most OECD countries, is 
particularly striking (table 6). In most countries, the tertiary sector has tended to hold up well and employment in this sector has actually grown though the relative and absolute expansion of this sector has not been able to check the adverse developments in overall output and employment.

It has been argued that the massive rise in the real price of oil in late 1973 and the smaller but nevertheless sharp rise in 1979 have contributed to the recession because of their effects on the terms of trade of the OECD countries. One estimate puts the effects of the 1973 price increase at about 2.5 per cent of OECD GNP12/. Yet much of the surpluses of the major oil exporters found their way - directly or indirectly - to the OECD countries anyway. The rise in the oil price would cause at the worst a "once and for all" rise in the general level of prices rather than sustained inflationary pressure. What the oil price hike - soon to be followed by the rise in price of all forms of energy - called for was a reduction in real wages were employment levels to be maintained $13 /$. The unwillingness to accept this "greatly increased but did not totally transform the problem of deflation"14/. The real problem for the OECD countries as a consequence of the oil price hike. was that of urgent structural adjustment: the automobile and truck industries and their associates were dealt a heavy body blow. The price of many components of capital equipment also rose as a consequence of the oil price hikes. Those countries which could show some flexibility with regard to reducing real wages and diversification in industry (including the large scale use of robots), like Japan, have done relatively well, while those who were unable to do so, like the UK, itself a net oil exporter, have fared relatively badly.

The "anti-inflationary" (or deflationary) policies followed by many OECD countries since the 70 s to deal with the inflation aspect of "stagflation" have proved successful only in containing inflation. Indeed, government policies have also had the effect of contributing to high real rates of interest, exacerbated both domestically and internationally by the "divergent" monetary and fiscal policy stance in the US; and high real rates of interest are not conducive to increased investment. The curtailment of the public sector, itself a major consumer of "public goods" such as education and heaith (and a potential customer for capital goods relating to infrastructural development and for housing) has not been helpful in maintaining the level of aggregate demand or in stimulating existing "leading sectors" or potential ones such as energy generation and leisure related activities. Moreover, the "tough" monetary policies aimed at reducing the rate of increase of the money stock-rather than the stock itselfcan, while stifling inflationary pressure and expectations, do little per se to generate the stimulus for increased investment in existing or potential "leading sectors". Indeed, 
they make recession a virtual certainty before recovery in the real economy can begin.

Monetarists have tended to blame the dismal economic performance largely on the efficiency-aistorting effects of the economic policies followed by governments in the early and mid 1970s. The following of expansionary policies by many OECD countries in the early $70 \mathrm{~s}, 1$ argely with the aim of sustaining aggregate demand, did nothing to help to cure the malaise affecting their real economies: such policies could not in the long run bring about a sustained rise in real income but instead led to inflation and fuelled inflationary expectations. Indeed, in certain instances, as in the attempt at sustaining aggregate demand in the UK, it enabled highly unionised labour to obtain a rising share of the national product without a concomitant increase in productivity, thereby stultifying growth and jeopardising the level of employment 157 .

While factors like increased female participation rates in the labour force have contributed to the problem, they are not the major determinants of unemployment. The recent surge of unemployment has been very disconcerting. is largely a belated response of individual businesses (of either reducing staff or going into liquidation) to the inimical environment in general and the low rate of return on capital and levels of capacity utilisation which are in turn manifestations of more fundamental influences that have persisted for some time.

Effects of the recession on developments in the international economy and on international economic relations

We have been dealing with a malaise from which few economies - whatever their type - can be insulated, given the degree of international interdependence. The dependence on foreign trade in goods has shown a marked tendency to increase in the post-war period (see table 2) to quite high levels for most countries - the US included. There is also now a susbstantial trade in services.

Trade flows are interlocked with growth performance, and it appears that the current stagnation in world trade stems largely from the recession in the large countries, notably the US, that constitute the major markets. Those countries that obtain much of their export and national incomes from primary products are particularly vulnerable as prices - with the exception of petroleum, the price of which has been hitherto' determined by the regulation of supplies from a cartel of major producers - tend to fall substantially in response to recession in the major industrialised countries. 
Matters have been exacerbated by the "dumping" of the agricultural surpluses of some developed country products. which has resulted in low prices for a few agricultural products, which.however, have a major impact on the foreign exchange earnings of many developing countries. International action on formation of commodity agreements has been generally ineffective. From 1977 to 1982 , real export earnings of the low-income developing countries, which depend heavily on primary products, fell by about 23 per cent and for other net oil-exporting (non-NICs) developing countries by about 2 per cent 16 .

Growth in many of these countries has been at minimal - if not negative - levels largely due to external factors. Not surprisingly, foreign investment has not stepped in to augment external resources, capacity to borrow from banks has been 1ittle, while increase in assistance in the form of aid and borrowings from international bodies has at best been marginal. For a few "dynamic" (largely) nonoil exporting developing countries with substantial potential for growth, the adverse external developments were "smoothed over" and growth potential enhanced by the re-cycling of "surplus" funds by the banks. This has proved to be a shortterm palliative. At best, the funds have dried up for a long time: at worst, the inability of many borrowers to honour their loan commitments has brought about a potential situation of a major crisis for international and domestic banking systems in major economies, not altogether different from what happened after the New York Stock Exchange went "bust" in 1929. Moreover, these developments have tended to stymy growth in a major "dynamic" area of the wor1d economy.

The momentum for further trade liberalisation has been lost and instead the level of protectionism has tended to increase with the increase taking on a covert rather than an overt form (in relation to obligations under the GATT Charter). While the increase in protectionism has hitherto been particularly felt. by developing country exporters of some manufactures in which they have a clear comparative advantage, the major trading country blocs of the EEC and the US, after having put pressure on Japan and some of the Third World countries to restrict exports to them are now involved in trade disputes with each other. Furthermore, pressures for protectionism as a means to get national economies out of the slump and to halt slides into massive unemployment levels in certain industries are escalating and the full effects of these may yet make themselves felt.

The international monetary system - which was based on the fixed exchange rate system of Bretton Woods - came under severe pressure by the early $70 \mathrm{~s}$ on account of the 
different economic performance and monetary policies followed by the major economies. The system. of "managed" floating rates that was adopted in 1973 has not only brought about uncertainty with respect to investment and trade, but reduced some of the efficacy of monetary policies because of the susceptibility of the exchange rate to change on account of flows of short-term funds when interest rates are varied. Concern about domestic inflation has influenced the stance taken by major economic powers with regard to decisions on the increase of international liquidity, which has been kept to a minimum, thereby stifling a potential stimulus to international trade and growth throughout the world economy.

III. The Inter-War Depression

The background

Many views exist as to the causes of the inter-war depression. Friedman has judged that its origin lay largely in the failure of monetary policy in the US, and specifically in the decline in the money stock and velocity 17 /, while Samuelson has considered it the result of the random occurrence of a series of accidents18/. Other explanations are the saturation of the market or a series of disastrous policy measures at the national and international levels $19 /$ or the loss of income by primary producers (which reduced aggregate demand, given their relative importance in the interwar period, especially in the US) through adverse movements of the terms of trade: there is also the view that it was a long-term cyclical decline on account of adverse developments with regard to the "leading sectors". Other views are that the $30 \mathrm{~s}$ represented the trough of a long-term ( 50 year) wave, or that it was a manifestation of the inevitable decline of capitalism.

The inter-war period saw business cycles of great ferocity, substantial and sustained reductions of output (or a lengthy period of depression) right up to the beginning 
of the War, dismal performance with regard to investment and concomitant developments with regard to employment. There was, in addition, a sustained reduction in the general level of prices, which tended to move in the same direction, though not with the same intensity, as output. The volume and values of trade were substantially reduced and there was a particularly severe impact on real incomes of the nonindustrialised countries. Private international capital flows were reduced with adverse consequences. In all, severe strains were imposed on the international economic system, which very soon ceased to exist: All these developments were of course, inter-related.

The situation in the $20 \mathrm{~s}$

It would be misleading to deal with the Great

Depression of the $30 \mathrm{~s}$ in isolation from the rest of the interwar period. Indeed, the events of the preceeding decade are of some relevance to explaining both the events of the $30 \mathrm{~s}$ and, to a lesser extent, today's recession. The end of the First World War called for substantial changes in the supply side of the major economies, to cater to peace-time demand.

Furthermore, the impetus for growth could no longer come from the "leading sectors" of yester year: changes on the supply and demand sides were-called for. In the US, which produced very largely for the domestic market, the automotive sector (together with the consumer electrical goods sector and urban construction) soon began to supply an ever increasing demand and was able in the main to sustain the economy right up to 192920 . In the European economies, not only was the post war adjustment problem much greater, but there were no new "leading sectors" that could propel the economies forward until re-armament got into high gear at the end of the $30 \mathrm{~s}$ : the automobile and durable consumer electrigal goods became areas of mass consumption only in the $50 \mathrm{~s}$.

Highlighting the problems of post-war adjustments, there was a recession, followed by rapid fluctuations in output and in prices, which fluctuated more. But differences were manifest among the major economies and exacerbated by fluctuations in the national money stock. The US suffered an 18 and 4 percent $22 /$ decline in nominal and real incomes respectively in 1921 compared with 1920, while its money stock declined by 9 per cent. But its real income rose by 23 per cent between 1921 and 1923 and grew at 3.4 per cent per year up to $192923 /$. At the same time, the general price level was virtually static in the second period, though prices for primary products were drifting downwards. Unemployment was of negligible proportions, while wages rose slightly (by 5 per cent between 1925 and 1929). 
The UK economy behaved intially in a similar fashion to that of the US, but entered into a mini depression from mid 1921 with much chronic unutilised capacity in many of the key export industries: in cotton textiles, the UK lost ground to India and Japan and in shipbuilding, comparative advantage was soon lost to the Scandinavian countries. The wholesale price level rose by 33 per cent between December 1918 and June 1920 but then fell by about 50 per cent in 1922, declining slightly thereafter. $24 /$ Unemployment rose to 15 per cent of the labour force in $192325 /$ and failed to decline below 10 per cent partly because the pound was fixed in relation to gold in 1925 at pre-war parity, which overvalued the pound by about 10 per cent26/. It was only in 1929 that there was a sudden (but short-lived) spurt in activity with the impetus largely coming from automobile, chemicals and electrical goods industries.

Germany was seriously hampered in the immediate postwar period by the burden of reparations (though the UK and Francetoo had to pay war debts to the US) and the distorting effects of the 1922-24 inflation. Yet substantial inflows of US capital after the formulation of the Dawes Plan of 1924 helped to stimulate investment, 27 though there was no significant advance over pre-war rates. The French economy received a substantial boost through the return to the gold standard in 1926 at a rate that somewhat undervalued the Franc. $28 /$

In the 20 s there was large-scale US lending to Europe and to many developing areas (see table 7). The UK lendings were much smaller and more concentrated geographically. The foreign lendings, especially those of the US, did much to sustain the German economy, and to "lubricate the flows of international trade", and enabled the level of aggregate demand in the periphery to increase. Moreover, the rapid growth of the US economy was helping to keep world trade buoyant.

\section{Developments 1929-32}

US funds, were being "diverted" from overseas by 1928 to finance the stock market boom, $29 /$ thus exerting much deflationary pressure externally. By 1929 , several ominous developments were discernible. There was a decline in the rate of investment - already low in many major countries outside the US (see Table 8); and inventories were building up in several major economies, including the US.

The New York Stock Market collapse though in part "a symptom of the underlying forces making for a severe contraction in economic activity .... must have helped to deepen the contraction". 30 The subsequent banking collapse and monetary policy adopted were largely to be responsible for the US money income declining by 53 per cent in the period 
Table 7 Pre-War Net Capital Exports $(-)$ and Imports $(+)$ of Countries on a

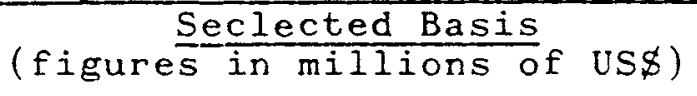

A. Industrial

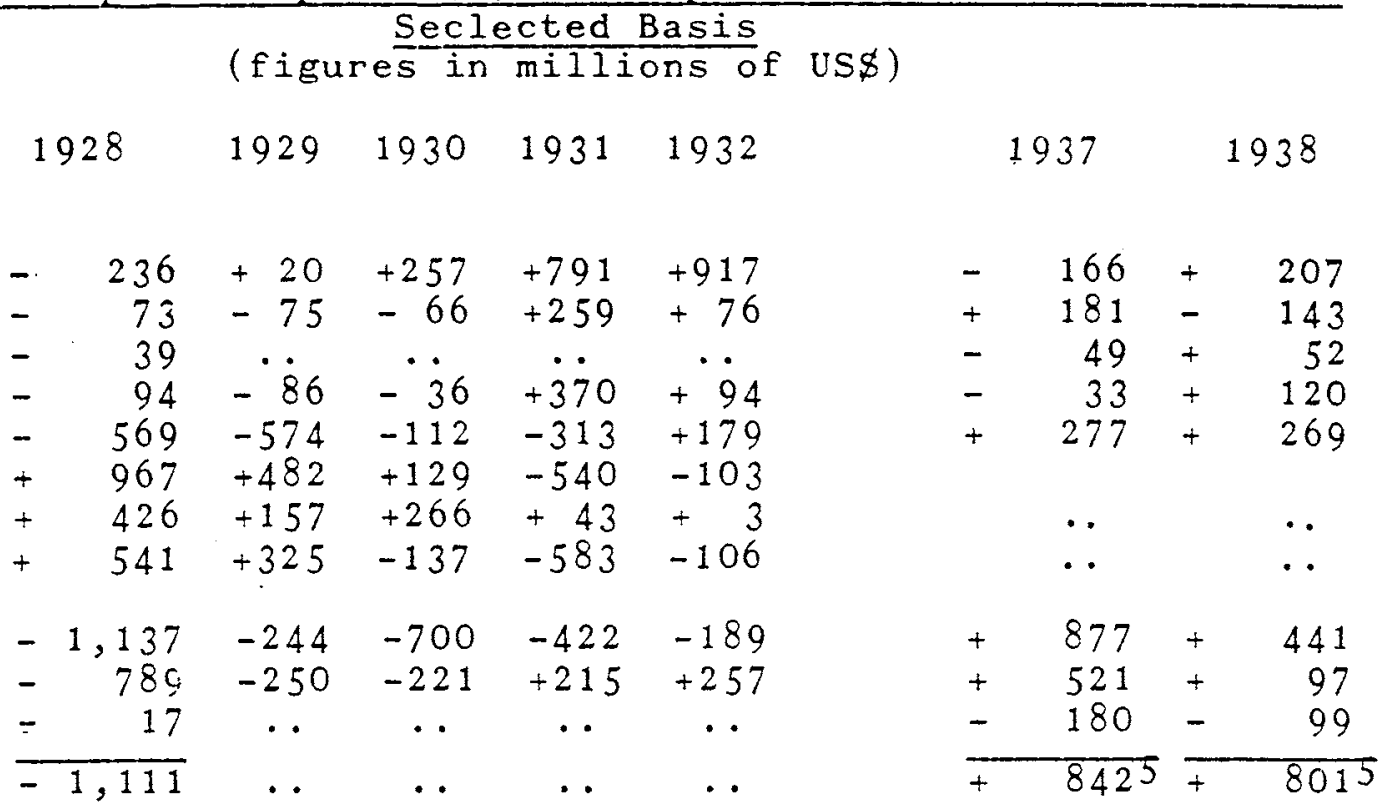

B. Non-industrial

\begin{tabular}{l} 
Countries \\
\hline Argentina \\
Australia \\
South Africa \\
India \\
Indonesia \\
Sub-total of \\
listed \\
countries
\end{tabular}

$$
\begin{array}{crcccc}
+ & 131 & -10 & +287 & -89 & +10 \\
+ & 209 & +250 & +40 & -50 & -31 \\
+ & 48 & \ldots & \ldots & \ldots & \ldots \\
+ & 5 & \ldots & \ldots & \ldots & \ldots \\
+ & 4 & \ldots & \ldots & \ldots & \ldots
\end{array}
$$

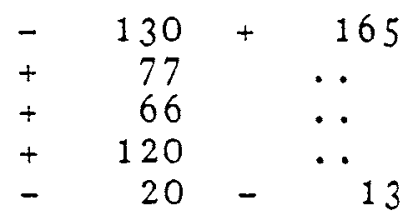

C. Memo item

World imports
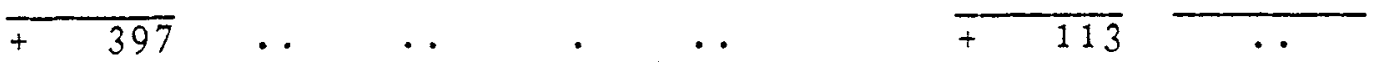

$31,738 \quad \ldots \quad \ldots \quad \ldots \quad \ldots$

. not available

1. Short and long term unless specified.

2. Includes French Overseas Territories.

3. Excludes Austria and the Sudetenland.

4. Includes Denmark, Norway and Japan.

5. Incomplete total.

Source: GATT; Trends in International Trade (Geneva, 1958) p.53 quoting UN Capital Movements during_the Inter_War_Period, 1949 


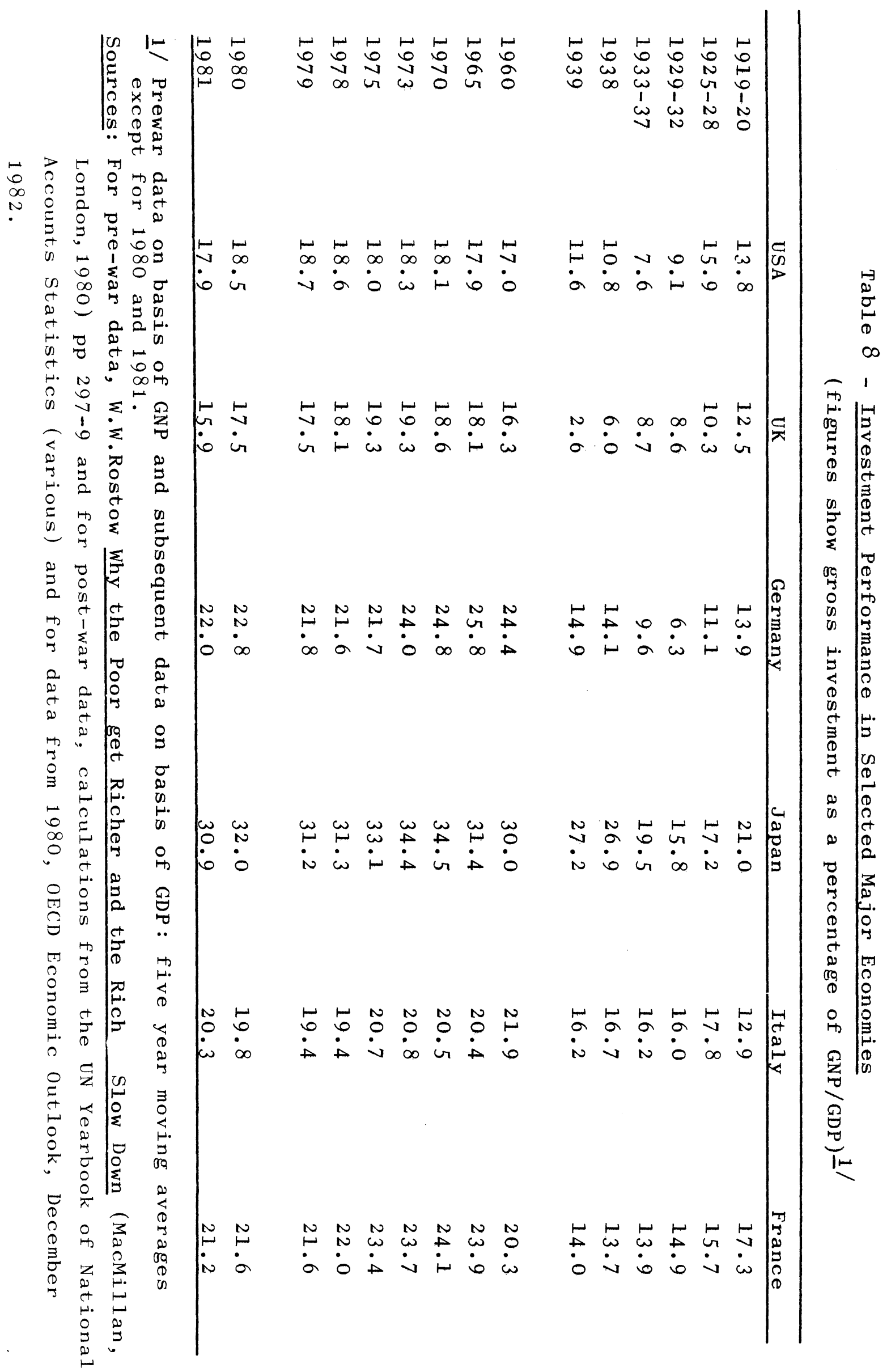


1929-33, while the net national product decline by 36 per centli1. Between October 1929 and October 1930 Us production fell by 27 per cent and the price level by 14 per cent. Unemployment rose from negligible levels to 3.1 per cent in 1929 , and very sharply after that: it was responding to output decline after a short time-lag.

The effects of the US depression were felt by the rest of the international economy: the system of the gold exchange standard rendered the "international financial system more vulnerable to disturbances" $32 /$ especially as the US did not allow its money supply to expand when there was an inflow of gold. The big fall in US imports enabled the balance of payments to stay in surplus until June 1930, but the substantial decline in US imports on the onset of its depression had a serious impact on export earnings (and hence incomes) of others, especially those heavily dependent on primary products: in the period 1929-32 US imports declined from $\$ 7.4$ billion to $\$ 2.4$ billion. $33 /$ Furthermore, US lending overseas continued to decline and was instrumental in bringing about severe strains on the banking systems of Germany and Austria (and creating a suitable climate for radical political change), besides adversely affecting investment overseas and trade flows.

The UK economy soon felt the adverse impact of the US collapse 34 . National income declined sharply and unemployment rose from 1.5 million in 1929 to 3.4 million, or to 15.6 per cent of the labour force, in 1932 . The depreciation of sterling in late 1931 (by the. UK leaving the gold standard) was a belated attempt to stimulate exports and reduce the impact of the world recession and to halt the "run" on sterling emanating from the European banking crisis. The depreciation of sterling was followed briefy by a deflationary policy. Throughout the crisis, the UK government was curbing expenditure and achieved a budget surplus - even at the cost of reducing unemployment benefits. By June 1932. however, a policy of "cheap" money was being followed: the discount rate was a mere 2 per cent $\underline{35}$ /.

The highly deflationary policy Germany was following between 1930 and $1932,36 /$ as well as the effects of the US collapse and the strains on its commercial banking system after the crisis of the Credit Anstalt of Vienna in the Spring of 1932 , saw unemployment rising very rapidly from 1.2 million in 1929 to nearly seven million, or 43.8 percent of the labour force, accompisied a substantial decline in real income. France was not immediately much affected by the general recession. Although deflationary policies were adopted, the decline caused to output and unemployment (which was a mere 500,000 largely due to the expulsion of "surplus" foreign workers) in $1930 / 31$ was not comparatively severe. But by 1932 , exports had contracted by over half and were slowing down the economy. 
World trade declined substantially in terms of volume and value, through the income and price effects that emanated from the depression between 1929 and 1932 . The volume and unit price of exports of manufactures fell by about $35 \%$ each. For the primary producers, the export prices fell by about 50 percent, though volume declined little. Many primary products, the demand for which was related to investment demand, experienced even heavier falls in real prices. Export earnings of primary producers declined from $\$ 19$ billion in 1929 to $\$ 7.5$ billion by $193238 /$. Trade problems were exacerbated by the dumping of surplus wheat by the USSR, and the competitive depreciations of currencies (by Australia, New Zealand and Argentina), which were only mutually frustrating for these agricultural producers.

The decline in the exports of the primary producers, which led to heavy gold losses. $39 /$ had catastrophic effects on their income levels and government revenues. A few relatively successful commodity arrangements established under the aegis of the colonial powers in products where metropolitan capital was heavily involved mitigated the falls in export earnings and incomes of a small number of countries. There were no "compensatory" inflows of foreign investment either: instead, flows had all but dried up.

The onset of the depression exerted a stimulus for a massive and immediate increase in protectionism. While the primary product exporters, 1 ike India and Australia, increased protection in 1929 , the US Smoot-Hawley Act of 1930 (debated in Congress in 1929) paved the way for a spate of "retaliatory" actions, by Canada, Italy and France which affected imports from all sources. The Imperial Preference Scheme of 1932 created a large trading area that. discriminated against the rest of the world. It is little wonder that trade as a proportion of national income fell substantially (see table 2). The international payments system, too, began to disintegrate. A few countries continued to stick with the gold standard while some abandoned it in favour of the gold exchange standard and others for the severance of the link with gold and a few resorted to the formation of payments agreements that verged on barter trade. The single major attempt to obtain international cooperation in dealing with what was becoming a global problem founciered on the rocks of "immediate-term" national self interest.

Developments $1933-39$

In the period up to 1939 there was a limited up-turn of the world economy, the short sharp recession of 1938 , and a recovery from it under the impetus of government policy and 
re-armament. In no area was the performance spectacular. The period also saw countries intensify inward looking policies in their endeavours to escape from the $i 11$ effects of the world recession.

The US industrial production staged a brief recovery to 1923-25 levels by July 19.3 .3 but faltered and only reached this level again in December $1935 \underline{40}$ and in mid 1937 when it exceeded this level by a relatively small margin before soon falling by 40 per cent. The US national income in 1937 was a little higher ( 3 per cent) than in 1929 real terms 41 but per capita income had fallen and labour force had risen by about 10 per cent. Highlighting the mediocre performance, investment was low. Unemployment remained high: it was 23 per cent of the labour force in 1933 and 18 per cent in 1935: by 1938 it was up to 19 per cent (see table 4). The price level in 1937 was about 20 per cent lower than in 1929; it, fell again in 1938 and the price level in 1941 was 8 per cent below that of $1929.42 /$ The US performance was despite the steps taken to depreciate the dollar in relation to gold, moderately expansionary efforts at stimulating the economy, a heavy influx of "refugee" capital from Europe and substantial public outlays on infrastructural development.

The UK economy was the first to recover to 1929 levels (by 1934) in terms of industrial output: but the $20 \mathrm{~s}$ were not years of substantial growth. While there was some progress in automobiles, chemicals and electrical goods, the traditional industries remained depressed. The national income was not much higher in 1938 than in 1933, despite the policy of "cheap" money fuelling a housing construction boom. Public policy was in general largely deflationary and there was no major effort on the part of the government to stimulate the economy. Investment, too, did not rise substantially. Unemployment declined from 16 per cent in 1932 to about 8. per cent in 1937 , but rose next year to 9 per cent (Table 5).

In Germany, there was rapid economic recovery under the National Socialist Government's expansionary fiscal policy, coupled with a public works programme and the return of business confidence. Investment began to pick up. Unemployment fell from 6 million in october 1933 to 2.8 million in February 1935 and 1.2 million two years later. France, belatedly - in 1936 and again in 1938 - devalued; exports had declined further to Ff 1300 million by $1935 \frac{43}{4}$, from FF 3600 million in 1930 and FF 1500 million in 1932 . Real income fell by 13 per cent by 1935 whereas prices fell by about 20 percent under the impact of deflationary economic policy. Devaluation helped to stimulate the economy a little but by 1938 little real advance had been made. Investment was at low levels. 
World trade remained in the doldrums. The volume of world trade in 1937-8 was 7 per cent below the level of 1928.44 The value of trade at 24.4 billion dollars in 1937 was substantially below 31.7 billion dollars, the value of trade in 192845 . In 1938, prices of primary products were 31 per cent below those of 1928 while those of manufactures were 17 per cent lower. As a percentage of GNP, trade had declined substantially: it was no longer even the handmaiden of growth. The contraction owed much to the trade barriers being imposed with increasing severity - the US Tariff Reciprocity Act notwithstanding - and exchange controls, especially in Germany and Italy, as well as the relative stagnation of the world economy, but less to the so called "competitive devaluations" of the major currencies, because other than in the very short term they tended to cancel each other out.

Capital flows behaved somewhat perversely, with "refuge" capital moving to the US despite the relatively sluggish performance of that economy (table 8). US capital outflows, too, 46 declined, and there was understandably relatively little investment in the non-industrialised countries.

The chronic inter-war depression was a phenomenon that affected all (market economy) countries, but its intensity, duration, impact and indeed some of its underlying causes were often very different nationally. Yet the depression was truely international: the massive declines in income, especially in the US, soon adversely affected trade flows and incomes in other countries: international capital flows were reduced and had further adverse repercessions. Government policy, especially of the major economies, had often serious repercussions for the rest of the world. The efforts of the various countries to insulate themselves from the adversities of the depression only worsened the problems of all.

\section{Possible causes of the inter-war depression}

While there was clearly no single cause for this depression, real factors - as acknowledged by Keynes and Friedman alike - had a large role to play. In most countries (with the possible exception of the US) old "leading sectors" had to be replaced by those that were contemporaneously needed. Yet, the environment of the period, which became increasingly unattractive to private investment, made it unlikely that the challenge would be taken up. As the depression got on its way, business confidence, and with it investment demand, faltered, bringing about a major fall in aggregate demand. 
There was, as Galbraith succintly put it, a lack of "economic intelligence" on the part of the state, with the important exceptions of Nazi Germany and the "piecemeal" attempts by the Roosevelt Administrations to get the US economy "back on course". In general, there was reluctance to stimulate economic activity, with politicians haunted by the spectre of the type of hyper-inflation that bedevilled Germany, Austria and Hungary in the early 20 s.

IV. Comparisons of the 30 s and the Present Recession

Although in both periods there have been adverse developments with regard to output, employment, investment, world trade, and major changes in the general level of prices, an essential difference is one of scale. Indeed, the present period may be broadly characterised as a recession rather than as a depression, which is an apt description for the inter-war period.

With regard to output, as seen in table 3 , there was a faltering in and indeed a slightly negative rate of growth over a relatively short period in the $70 \mathrm{~s}$. The interwar period saw three massive falls in output, and general stagnation in output levels over a very long period of time. Investment has behaved in a manner similar to output: it has receded a little, but not totally collapsed as in the interwar period.

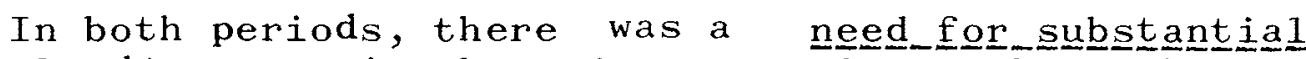

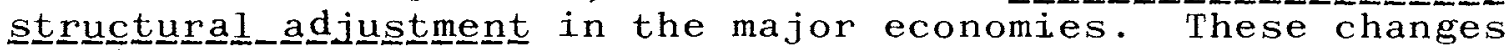
involve not only the re-allocation of resources and changes in patterns of national expenditure but also changes in the relative shares of the national product that accrue to labour and capital. In neither period, were these issues squarely faced up to by public policy and acted upon. Instead, therewas a tendency for public policy to attach a diminjshing role to the public sector in the expectation that greater (relative) involvement of the private sector would eventually bring about the necessary changes or at least bring about greater economic efficiency. Such a policy was not successful in the inter-war period to any satisfactory degree, and although all circumstances were not identical, it is likely to be devoid of major success in anything but the very long term.

With regard to unemployment, which has been recently rising at an alarming rate in terms of numbers out of work, the rate of unemployment is in general well below the rate of the worst years of the depression. It is not projected to increase much further, and has possibly risen - by a few percentage points at least - because of increased female participation rates 47 . On the other hand, the depressing 
outlook with regard to output applies here too: in addition, it is not certain, in the light of the inevitable structural adjustments on the one hand, and possible major increases in labour productivity in many economic activities on the other, that the so called "natural rate of unemployment" will not remain at historically high levels for a very long time to come.

Furthermore, though the numbers unemployed are quite high and youth unemployment is a major problem, the phenomenon of unemployment is itself not as painful an experience today (at least in the developed countries) in contrast to the $30 \mathrm{~s}$. Much improved social security systems and unemployment benefits effectively guarantee with the possible partial exception of the US - that the unemployed and their families have a standard of living, which though well below that of most of the employed, nevertheless does not entail deprivation of basic requirements.

Trade has slowed down of late, but its decline hitherto has been marginal. This has to be contrasted with the massive and sustained reduction in the volume and values of trade in the period 1928-39. But the poorer primary product exporters have been affected in a not very dissimilar fashion in the current recession from the worst days of the $30 \mathrm{~s}$. And of late, the other non-oil exporters have encountered severe contraction, either because of the drying up of their sources of (external) capital or relative stagnation in most export markets, or both, a situation that prevailed in both periods, for most developing countries.

The general level of prices fell substantially in the inter-war period, when output fell and in broad terms the two moved in parallel fashion. However, in the $70 \mathrm{~s}$ and early $80 \mathrm{~s}$ a major problem as been the rate of (positive) growth of the general level of prices. In the first recession (1974-5) and the recovery (1975-9) the movements of the general level of prices and real output were anything but parallel: there was indeed "stagflation" between 1974 and 1975 - no growth but a rapidly rising general level of prices. In 1979-82, the rate of growth of output and the rate of growth of the general level of prices showed a little less "stagflation" but the rate of rise in the price level only declined significantly after about two years of recession in a period when "antiinflationary" policies were generally operative.

International economic relations are admittedly strained and similar pressures to those in the 30 s have emerged. While there is a long way to go before they manifest themselves in concrete actions on the scale of the $30 \mathrm{~s}$, 
these pressures are bound to be exacerbated if output and employment levels remain stagnant. Developed countries now depend far more on each other (and indeed on the rest of the world) and the wisdom of not fragmenting the international trade and payments system is apparent to the major actors. At the same time, concern over pressing national economic problems and the lack of full consensus on how to deal with them at the national and international levels inhibit these countries from tackling their problems through a concerted action or from making innovations relating to the international economic system.

Among the factors accounting for the differences in the behaviour of the key variables, the following could be perhaps usefully highlighted.

First, contractionary though monetary policy has been at times, it has never brought about (or permitted) a reduction in the money stock (as in the US in the $30 \mathrm{~s}$ ) but rather been concerned with bringing about a reduction in the rate of growth of money demand.

Secondly, the state is heavily involved in national expenditure - both in consumption and investment - and a significant downward shift in the state's expenditure is very "sticky" except over the very long run. Although many governments of late have tended to give priority to holding down inflation, over checking the rise in unemployment, there are several constraints that prevent in practice the following of "tougher" policies, especially as the stimulative role of public expenditure - at least in the short run - is recognised by all.

Thirdly, manufacturing is no longer the sector that dominates the economy with regard to value added and employment as it was in the inter-war period, and the very poor performance in output (and fall in employment) in this sector for the OECD countries as a group in the $70 \mathrm{~s}$ has not led to major reductions in overall output and employment levels, as in the $30 \mathrm{~s}$. 


\section{Footnotes}

1. For the purpose of this exercise inflation is defined as a sustained increase in the general price level, reflation as an increase in real output in the short run followed by a lower growth rate and a higher price level in the longer run, deflation as a reduction in the level of real economic activity, depression as a state where there is unemployment of labour and capital for a substantial period of time and recession as a mild form of depression: cf Brian Griffiths, Inflation (Weidenfeld and Nicolson, London, 1977); pp 10-12.

2. James E. Meade, Stagflation, Vol.1 (George Allen and Unwin, London, 1982), p 3 .

3. W.W. Rostow, why the Poor get Richer and the Rich Slow Down (MacMilian, London, 1980), pp.55 and 95 .

4. Ibid, p. 95 .

5. James E. Meade, op cit, p. 16.

6. OECD, Economic Outlook, December 1982, p. 152 .

7. Michael Parkin, "Inflation without Growth: A Long Run Perspective on Short Run Stabilization Policies" in Karl Brunner and Allan Meltzer (editors), Stabilization of the Domestic and International Economy, (Carnegie Rochester Conference Series, North Holland)p. 51. Also Assar Lindbeck, "The Recent Slowdown in Productivity Growth", a paper presented at a Conference of the Royal Economic Society, London,July 22, 1982, and "Financial Times" of October 18, 1982 quoting an OECD study .

8. Assar Lindbeck, op cit. Also, Herbert Giersch and Frank Wolter, "On the Recent Slowdown in Productivity Growth in Advanced Economies", a paper presented at a Conference of the Royal Economic Society, London, July 22,1982 .

9. IMF, World Economic Outlook, 1983,p. 176.

10. Robert E. Lucas, "Understanding Business Cyoles" in Karl Brunner(editor), The Great Depression Revisited (Nijhoff, the Hague, 1980) p.25.

11. W.W. Rostow, op ci.t,pp.37-38.

12. Assar Lindbeck, op cit. 
13. James R. Meade, op cit, pp. 3 and 14 .

14. Ibid, p. 29

15. Ibid, pp. 3 and 24-25.

16. IMF, World Economic Outlook, 1983, p. 182 .

17. M. Friedman and A. Schwartz A Monetary History of the $\frac{\text { United States 1867-1960 }}{\text { Princeton, 1971). }}$

18. Charles P. Kindleberger, The World in Depression 1929-39

(Allen Lane, London, 1974$)$ pp. 19-20

19. Ibid, pp. 291-307.

20. W.W. Rostow, op cit, p. 35 .

21. Ibid, p. 37 .

22. M. Friedman and A. Schwartz, op cit, p. 232 .

23. Ibid, pp. $242-43$.

24. J.W.F. Rowe, Primary Commodities in International Trade (Cambridge University Press, Cambridge, 1965) p.78.

25. Charles P Kindleberger, op cit, p.45.

26. Ibid.

27. Ibid, p. 38 .

28. Ibid, pp. 48-52.

29. Ibid, pp. $70-72$.

30. M. Friedman and A. Schwartz, op cit, p. 306.

31. Ibid, p. 301 .

32. Ibid, p.359

33. The Beveridge Report (HMSO, London,1942) p. 219 .

34. Jim Tomlinson "Unemployment and Policy in the $1930 \mathrm{~s}$ and 1980s", Three Banks Review, September 1982 .

35. Charles P. Kindleberger, op cit,pp.180- 1 .

36. Ibid, p. 139 . 
37. GATT (Report by a Panel of Experts), Trends in International Trade (Geneva, 1958) p. 13.

38. Ibid.

39. Charles P Kindleberger, op cit,pp. 101-104.

40, Ibid, p. 233 .

41. M. Friedman and A. Schwartz, op cit; p. 493.

42. Ibid, p. 545 .

43. Charles P. Kindleberger, op cit, p. 248 .

44. GATT, op cit, p. 20 .

45. Ibid, p. 131 .

46. Charles P. Kindleberger, op cit, p. 283.

47. For example, 40 per cent of the labour force in the UK currently, compared with 20 per cent in the inter-war period. 